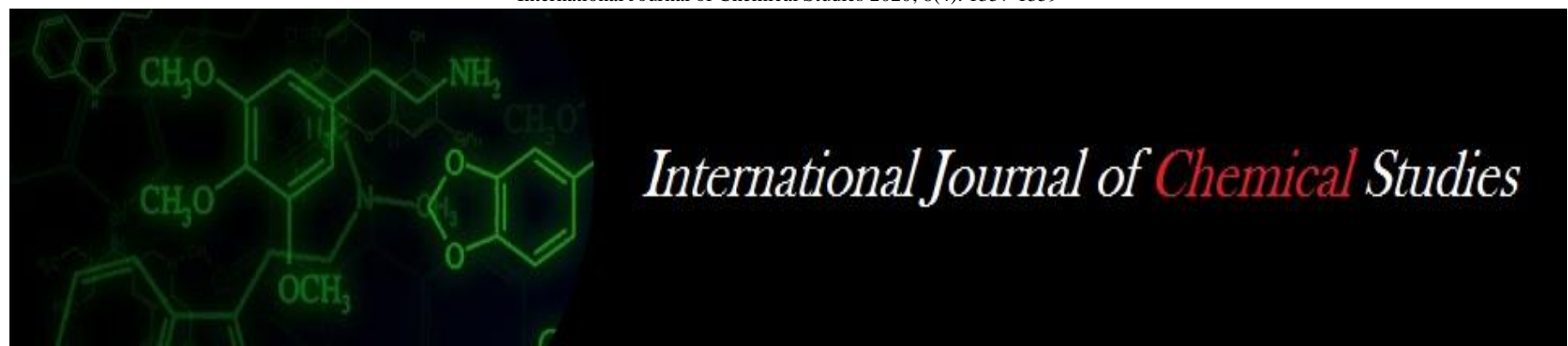

P-ISSN: 2349-8528

E-ISSN: 2321-4902

www.chemijournal.com

IJCS 2020; 8(4): 1357-1359

(C) 2020 IJCS

Received: 16-05-2020

Accepted: 20-06-2020

\section{TSSK Patro}

Acharya NG. Ranga Agricultural

University, Agricultural

Research Station, Vizianagaram,

Andhra Pradesh, India

\section{KE Georgia}

Acharya NG. Ranga Agricultural

University, Agricultural

Research Station, Vizianagaram,

Andhra Pradesh, India

\section{S Raj Kumar}

Acharya NG. Ranga Agricultural

University, Agricultural

Research Station, Vizianagaram,

Andhra Pradesh, India

\section{N Anuradha}

Acharya NG. Ranga Agricultural

University, Agricultural

Research Station, Vizianagaram,

Andhra Pradesh, India

\section{Y Sandhya Rani}

Acharya NG. Ranga Agricultural

University, Agricultural

Research Station, Vizianagaram,

Andhra Pradesh, India

\section{U Triveni}

Acharya NG. Ranga Agricultural

University, Agricultural

Research Station, Vizianagaram,

Andhra Pradesh, India

\section{Management of pearl millet blast through fungicides and biocontrol agents}

\author{
TSSK Patro, KE Georgia, S Raj Kumar, N Anuradha, Y Sandhya Rani \\ and $U$ Triveni
}

DOI: https://doi.org/10.22271/chemi.2020.v8.i41.9789

\begin{abstract}
The in vivo experiment was conducted at Agricultural Research Station, Vizianagaram against pearl millet blast revealed that all the treatments showed significant reduction in blast disease incidence in pearl millet. Among all the treatments T3i.e., foliar application of Pseudomonas fluorescens at 20 DAS and Trifloxystrob in + Tebuconazole at 35 DAS was found effective with least disease intensity of blast $(14.1 \%)$, highest grain $(26.0 \mathrm{q} / \mathrm{ha})$ and fodder yield $(60.9 \mathrm{q} / \mathrm{ha})$. While the highest disease intensity (94.8) was noticed in the treatment T6i.e., control with lowest grain $(9.3 \mathrm{q} / \mathrm{ha})$ and fodder yiled $(26.3 \mathrm{q} / \mathrm{ha})$. The highest cost benefit ratio (2.5) was obtained in treatment $\mathrm{T}_{3}$.
\end{abstract}

Keywords: Biocontrol agents, fungicides, pearl millet, Pseudomonas fluorescens, Pyriculariagrisea, Trifloxystrobin + Tebuconazole

\section{Introduction}

Pearl millet (Pennisetumglaucum (L.) R. Br.) is one of the important cereal and drought tolerant crop grown in arid and semi arid tropics of Asia and Africa. It is highly nutritious which high amounts of iron and zinc (Rai et al., 2008) ${ }^{[12]}$. It is grown as dual purpose crop for grain and fodder purpose. In India, pearl millet is popular as bajra and is cultivated under rainfed conditions with an annual production of about 86.60 lakh tonnes (India stat 2019).

As, pearl millet crop is prone to number of diseases which is a major constraint in production causing low yield and economic losses. The fungal diseases that affect pearl millet such as, downy mildew or green ear disease (Sclerosporagraminicola), rust (Pucciniasubstriata var. indica), smut (Tolyposporiumpenicillariae) and sugary disease or ergot of bajra (Clavicepsfusiformis) which bothers both the farmers and researchers. On the other hand, leaf spots which are caused by pathogens like, Pyriculariagrisea, Bipolarissetariae, Cercosporapenniseti, Curvulariapenniseti, Drechsleradematioidea and Exserohilumrostratum destroys the foliage and thus reducing yield. Among the leaf spots, blast disease caused by Pyriculariagrisea which is considered as a minor problem during the past but now emerged as a serious problem affecting both forage and grain production of pearl millet in India (Lukose $e t$ al., 2007) ${ }^{[6]}$.

Although, host plant resistance is considered as the most economical and ecofriendly method of management of plant diseases. Hence, efforts are being made to understand inheritance of resistance to $P$. grisea and pathogenic variation in the pathogen so as to develop pearl millet parental lines and hybrids resistant to blast (Gupta et al., 2012) ${ }^{[2]}$. As, the blast disease in rice is primarily managed through host plant resistance, the pathogen has the ability to develop new pathogenic races leading to breakdown of resistance within few years (Ahn, 1994). Hence, extensive research is being carried out to manage blast disease in different crops using fungicides (Lukose et al., 2007, Narayana Swamy et al., 2009; Netam et al., 2014; Pagani et al., 2014) $[6,7,9,10]$. Hence, a research was executed to know the efficacy of fungicides and biocontrol agents.

\section{Materials and Methods}

The field experiment was conducted at Agricultural Research Station, Vizianagaram for the management of blast disease in pearl millet by using fungicides and potential biocontrol agents like Bacillus subtilis, Pseudomonas fluorescens and chitosan.

\section{TSSK Patre}

Acharya NG. Ranga Agricultural University, Agricultural

Research Station, Vizianagaram, Andhra Pradesh, India 
These isolates were collected from Department of Biological control, Vizianagaram. The experiment was laid out in randomized block design $(\mathrm{RBD})$ with three replications at spacing of $45 \times 15 \mathrm{~cm}$ with $3 \times 2.7 \mathrm{~m}$ gross plot size. Standard agronomic practices of NPK-50kg, $40 \mathrm{~kg}, 25 \mathrm{~kg}$ were followed at the time of crop growth period. The crop was sown in the second week of July 2019. A susceptible variety ICMV 155 was used in this experiment by imposing the following treatments: (Table 1).

Seed treatment was done with chitosan at the time of sowing with $3.75 \mathrm{~g}$ of chitosan for one $\mathrm{kg}$ seed. For foliar spray both the biocontrol agents ie., Pseudomonas fluorescens and Bacillus subtilis were applied @ 10 g/l. For foliar spray Trifloxystrobin + Tebuconazole was applied @ 0.4 g/l Two foliar sprays with biocontrol agents and fungicides were done at 20 days after sowing as first spray and at 35 days after sowing as second spray. The intensity of blast was recorded after seven days of each spray. Ten plants were selected randomly and labeled from each plot for scoring the disease intensity. These labeled plants were observed for disease intensity from upper, middle and lower leaves using disease rating scale of 0-9 (IRRI, 1988) ${ }^{[4]}$. The grain and fodder yield per ha were recorded. Standard Evaluation System (SES) for blast (IRRI, 1988) ${ }^{[4]}$.

The per cent disease intensity (PDI) was calculated by using the following formula

$\mathrm{PDI}=\frac{\text { Sum of individual disease ratings }}{\text { No. of observations assessed } \mathrm{X} \text { maximum disease rating }} \times 100$

Table 1: Details of the Treatments

\begin{tabular}{|c|c|}
\hline S. No. & Treatments \\
\hline 1 & Seed treatment with Chitosan @ 3.75g/kg seed + 2 sprays of Pseudomonas fluorescens $@ 10 \mathrm{~g} / \mathrm{l}$ after 20 DAS and 35 DAS \\
\hline 2 & Seed treatment with Chitosan @3.75g/kg seed +2 sprays of Bacillus subtilis@ 10g/l after 20 DAS and 35 DAS \\
\hline 3 & Spray treatment with Pseudomonas fluorescens @ 10g/1 20 DAS and Trifloxystrobin + Tebuconazole @ 0.04\% after 35 DAS \\
\hline 4 & Spray treatment with Trifloxystrobin + Tebuconazole @ 0.04\% 20 DAS and Bacillus subtilis @ 10g/l after 35 DAS \\
\hline 5 & Trifloxystrobin + Tebuconazole @ 0.04\% 2 sprays after 20 DAS and 35 DAS \\
\hline 6 & Control \\
\hline
\end{tabular}

Table 2: Blast disease rating scale

\begin{tabular}{|c|c|}
\hline Scale & Description \\
\hline 0 & No lesions \\
\hline 1 & Small brown specks of pinhead size without sporulatingcenter \\
\hline 2 & $\begin{array}{c}\text { Small roundish to slightly elongated, necrotic grey spots, about 1-2 mm in diameter with a distinct brown margin, lesions are mostly found } \\
\text { on the lower leaves }\end{array}$ \\
\hline 3 & Lesion type is the same as in scale 2, but significant number lesions are on the upper leaves \\
\hline 4 & Typical sporulating blast lesions, 3 mm or longer, infecting less than 2\% of the leaf area \\
\hline 5 & Typical blast lesions infecting 2-10\% of the leaf area \\
\hline 6 & Blast lesions infecting 11-25\% leaf area \\
\hline 7 & Blast lesions infecting 26-50\% leaf area \\
\hline 8 & Blast lesions infecting 51-75\% leaf area \\
\hline 9 & More than 75\% leaf area affected \\
\hline
\end{tabular}

\section{Results and Discussion}

The findings of the present study from Table 3 reveals that all the treatments showed significant reduction in blast incidence when compared to control. Among all the treatments $\mathrm{T}_{3}$ i.e., Foliar spray with Pseudomonas fluorescens at 20 DAS as first sprayand Trifloxystrobin + Tebuconazole at 35 DAS as second sprayproved to be best with least disease intensity $14.1 \%$. The next best treatment was $\mathrm{T}_{4}$ i.e., spray treatment with Trifloxystrobin + Tebuconazole 20 DAS as first spray and Bacillus subtilis after 35 DAS as second spray with $29.6 \%$ disease intensity. Foliar sprays with Trifloxystrobin + Tebuconazole at 20as first spray and at 35 DAS as second spray showed $38.5 \%$ disease intensity. 40.7 and 44.4 percent disease intensity was recorded in treatments $\mathrm{T}_{1}$ i.e., seed treatment with chitosan and 2 foliar spray of Pseudomonas fluorescens and $\mathrm{T}_{2}$ i.e., seed treatment with chitosan and 2 foliar spray of Bacillus subtilis, respectively. The highest disease intensity was recorded in control with $94.8 \%$.

In case of grain yield highest $(26.0 \mathrm{q} / \mathrm{ha})$ was recorded in treatment $\mathrm{T}_{3}$ i.e., Foliar spray with Pseudomonas fluorescens at 20 DAS as first spray and Trifloxystrobin + Tebuconazole at 35 DAS as second spray followed by $\mathrm{T}_{4}$ i.e., spray treatment with Trifloxystrobin + Tebuconazole 20 DAS as first spray and Bacillus subtilis after 35 DAS as second spraywith 22.0 $\mathrm{q} /$ ha. Foliar spray with Trifloxystrobin + Tebuconazole at 20 and 30 DAS alone recorded $19.0 \mathrm{q} / \mathrm{ha}$. The treatments with seed treatment with chitosan and 2 foliar spray of Pseudomonas fluorescens and Bacillus subtilis at 20 and 30 DAS with $15.0 \mathrm{q} / \mathrm{ha}$ and $12.7 \mathrm{q} / \mathrm{ha}$, respectively. The least grain yield was recorded in control $9.3 \mathrm{q} / \mathrm{ha}$.

Regarding fodder yield was highest was recorded in Foliar spray with Pseudomonas fluorescens at 20 DAS as first spray and Trifloxystrobin + Tebuconazole at 35 DAS as second spray $(60.9 \mathrm{q} / \mathrm{ha})$. Spray treatment with Trifloxystrobin + Tebuconazole 20 DAS as first spray and Bacillus subtilis after 35 DAS as second sprayrecorded $51.9 \mathrm{q} / \mathrm{ha}$ of fodder yield. The fodder yields of treatments Foliar sprays with Trifloxystrobin + Tebuconazole at 20 as first spray and at 35 DAS as second spray (46.2 q/ha) and seed treatment with chitosan and 2 foliar spray of Pseudomonas fluorescensat 20 and 30 DAS (40.2 q/ha) are significantly on par with each other followed by seed treatment with chitosan and 2 foliar spray of Bacillus subtilisat 20 and 30 DAS(39.1 q/ha). Control showed lowest fodder yield (26.3 q/ha). Foliar spray with Pseudomonas fluorescens at 20 DAS and Trifloxystrobin + Tebuconazole at 35 DAS was proved to be best with highest cost benefit ratio of 2.5 followed by spray treatment with Trifloxystrobin + Tebuconazole 20 DAS and Bacillus subtilis after 35 DAS with 2.1.

Two sprays of $P$. fluorescenswas effective in controlling the blast disease in finger millet (Ramappa et al., 2002) ${ }^{[13]}$. Sitther and Gananamanickan (1996) ${ }^{[15]}$ reported that six 
strains of Pseudomonas fluorescens showed their ability to inhibit the finger millet blast fungus. Seed treatment and two foliar sprays with Pseudomonas fluorescens most effective in reducing blast disease of finger millet (Kumar and Kumar, 2011) ${ }^{[5]}$. Netam et al., (2016) ${ }^{[8]}$ reported that foliar sprays of Pseudomonas fluorescenswas effective in controlling blast incidence. Trifloxystrobin + Tebuconazolewas found to be effective in managing the blast disease in pearl millet with higher yield (Ajay et al., 2018) ${ }^{[1]}$. Field experiment results of Sharma et.al., 2018 revealed that three sprays ofTebuconazole + Trifloxystrobin or propiconazolewas superior in reducing blast incidence with higher yields in pearl millet. Parmesh et $a l$, (2016) reported that rice blast was effectively controlled with Tebuconazole + Trifloxystrobin and resulted in higher yield.

Table 3: Efficacy of treatments on blast disease, effect of treatments on grain and fodder yield and benefit cost ratio

\begin{tabular}{|c|c|c|c|c|c|}
\hline S. No. & Treatments & Blast (PDI\%) & Grain yield (q/ha) & Fodder yield (q/ha) & BCR \\
\hline 1 & $\mathrm{~T}_{1}$ & $\begin{array}{c}40.7 \\
(39.6)\end{array}$ & 15.0 & 40.2 & 1.5 \\
\hline 2 & $\mathrm{~T}_{2}$ & $\begin{array}{c}44.4 \\
(41.7)\end{array}$ & 12.7 & 39.1 & 1.3 \\
\hline 3 & $\mathrm{~T}_{3}$ & $\begin{array}{c}14.1 \\
(21.9)\end{array}$ & 26.0 & 60.9 & 2.5 \\
\hline 4 & $\mathrm{~T}_{4}$ & $\begin{array}{c}29.6 \\
(32.9)\end{array}$ & 22.0 & 51.9 & 2.1 \\
\hline 5 & $\mathrm{~T}_{5}$ & $\begin{array}{c}38.5 \\
(38.3)\end{array}$ & 19.0 & 46.2 & 1.8 \\
\hline 6 & $\mathrm{~T}_{6}$ & $\begin{array}{c}94.8 \\
(77.2)\end{array}$ & 9.3 & 26.3 & 1.0 \\
\hline & $\mathrm{CV}(\%)$ & 7.1 & 5.9 & 9.6 & \\
\hline & $\mathrm{CD}$ at $5 \%$ & 5.4 & 1.9 & 7.8 & \\
\hline & S.Em. \pm & 1.7 & 0.6 & 2.5 & \\
\hline
\end{tabular}

\section{Conclusion}

The entire study showed that all the treatments are effective in controlling pearl millet blast. Further it is concluded that initial spray of Pseudomonas fluorescensand Trifloxystrobin + Tebuconazole as second spray was found superior in managing the blast disease.

\section{References}

1. Ajay K, Pandya RK, Bhagyashree S. Performance of botanicals and fungicides against blast of pearl millet (Pennisetumglaucum. ANN. Plant Soil Res. 2018; 20(3):258-262.

2. Gupta, SK, Sharma R, RaiK N, Thakur RP. Inheritance of foliar blast resistance in pearl millet (Pennisetumglaucum L. (R.) Br.). Plant Breed. 2012; 13:217-219.

3. Indiastat, 2018-19. https://www.indiastat.com/agriculture-data/2/stats.aspx

4. IRRI. Standard Evaluation System for Rice. In. International Rice Research Institute. Los Banos, Philippines, 1988, 54.

5. Kumar B, Kumar J. Management of blast disease of finger millet (Elusinecoracana) through fungicides, bioagents and varietal mixture.I nd. Phytopathol. 2011; 64:272-274.

6. Lukose CM, Kadvani DL, Dangaria CJ. Efficacy of fungicides in controlling blast disease of pearl millet. Ind. Phytopathology. 2007; 60(1):68-71.

7. Narayana Swamy HD, Sannaulla S, Dinesh Kumar M. Evaluation of new fungicides against rice blast in cauvery delta. Karnataka J Agric. Sci. 2009; 22:450-451.

8. Netam RS, Prafull Kumar, Yadav SC. Efficacy of BioControl Agents for the Management of (Pyriculariagrisea) Blast Disease of Finger Millet Under Field Condition of Bastar, Chhattisgarh. J Pure Appl Microbio. 2016; 10(3):2421-2425.

9. Netam RS, Tiwari RKS, Bahadur AN, Shankar D. In vitro and in vivo efficacy of fungicides against
Pyriculariagrisea causing finger millet blast disease. Int. J Plant Protect. 2014; 7:137-142.

10. Pagani A P S, DianeseA C andCafé-Filho A C. Management of wheat blast with synthetic fungicides, partial resistance and silicate and phosphite minerals. Phytoparasitica. 2014;42:609-617.

11. Pramesh D, Maruti, Muniraju K M, Mallikarjun K, GuruprasadG S,Mahantashivayogayya K, ReddyB G M, Gowdar S B and Chethana B S. Bio-efficacy of a Combination Fungicide against Blast and Sheath Blight Diseases of Paddy. J. Exp. Agric. Int. 2016;14(4): 1-8.

12. Rai K N, Gowda C L L, Reddy B V S and Sehgal S.The potential of sorghum and pearl millet in alternative and health food uses.Compr.Rev. Food Sci. Food Saf.2008; 7: 340-352.

13. Ramappa H K, Ravishankar C R and Prakash P. Estimation of yield loss and management of blast disease in finger millet (ragi). Proceeding of Asian Congress.Mycol.and Plant Pathol. Univ. Mysore 2002; p. 195.

14. Sharma R, Vishal L G and Madhavan S. Evaluation of fungicides for the management of pearl millet [Pennisetumglaucum (L.)] blast caused by Magnaporthegrisea. Crop Prot. 2018; 112:209-213.

15. Sitther V and Gnanamanickam S S. Biological control of blast disease of finger millet (Eleusinecoracana L.) and analysis of fertility of Magnaporthegrisea.Curr. Sci., 1996; 71: 144-147. 